\title{
EVALUATION OF YIELD QUALITY AND WEED INFESTATION OF COMMON VALERIAN (Valeriana officinalis L.) IN DEPENDENCE ON WEED CONTROL METHOD AND FORECROP
}

\author{
Cezary Kwiatkowski
}

\author{
University of Life Sciences, Department of Tillage and Plant Cultivation, \\ Akademicka 13, 20-950 Lublin, Poland \\ e-mail: czarkw@poczta.onet.pl
}

Received: 6.05.2010

\section{Abstract}

A field experiment involving the cultivation of common valerian was conducted on loess soil in Abramów (Lublin region) in the period 2007-2009. Qualitative parameters of herbal raw material obtained from this plant as well as in-crop weed infestation were evaluated depending on the protection method and forecrop. Hand-weeded plots, in which a hand hoe was used, were the control. In the other treatments, weeds were controlled using various herbicides and a mechanical implement (brush weeder). Potato and winter wheat + field pea cover crop were the forecrops for common valerian crops. A hypothesis was made that the use of a brush weeder and herbicides not registered for application in valerian crops would have a positive effect on this plant's productivity and weed infestation in its crops. It was also assumed that the introduction of a cover crop would allow the elimination of differences in the forecrop value of the crop stands in question.

The best quantitative and qualitative parameters of common valerian raw material as well as the largest reduction of incrop weed infestation were recorded after the application of the herbicides which were not type approved. The use of the brush weeder in the interrows also had a beneficial effect on productivity of the plant in question, but secondary weed infestation at the end of the growing season of common valerian turned out to be its disadvantage. Traditional crop protection methods used in common valerian crops were less effective in weed infestation reduction and they resulted in lower plant productivity and raw material quality. Potato proved to be a better forecrop for common valerian than winter wheat + field pea; however, this positive effect was not confirmed statistically. The following annual weeds: Chenopodium album, Galinsoga parviflora, Stellaria media, were predominant in the common valerian crop. Traditional weed control methods resulted in the dominance of some dicotyledonous weeds, such as Viola arvensis, Galium aparine, Capsella bursa-pastoris.

Key words: common valerian, biometric traits, essential oil, valerenic acids, mechanical and chemical weed control, forecrop

\section{INTRODUCTION}

Common valerian (Valeriana officinalis L.) belongs to the valerian family (Valerianaceae). This is a perennial whose roots and rhizomes are one of the most commonly used herbal raw materials. The abovementioned vegetative organs are rich in essential oil and valepotriates. In Poland, in particular in the Lublin region, common valerian belongs to the leading group of cultivated medicinal plants. In spite of a long-term tradition in growing this plant, we observe problems with obtaining herbal raw material of appropriate quality, and one of the reasons for this situation is onerous weed management or improper crop sequence (R u mi ń s k a, 1991; K w i a t k o w s k i, 2008a). The greatest deficiency is the control of dicotyledonous weeds, since in Poland there are few registered herbicides for foliar application which can be used after planting valerian seedlings when an increased competitiveness of weedy species occurs ( $\mathrm{K} \mathrm{w} \mathrm{i} \mathrm{a} \mathrm{t} \mathrm{k} \mathrm{o} \mathrm{w} \mathrm{s} \mathrm{k} \mathrm{i,}$ 2008b). Hence, there is an ongoing need to carry out research on the use of foliar-applied herbicides which are not type approved for use in common valerian crops as well as to seek effective methods of mechanical weed management. As shown in some studies ( $\mathrm{K}$ w i a tk ow ski, 2009), the cultivation of herbal plants with a wide row spacing $(30-50 \mathrm{~cm})$ makes it possible to use some known, but less frequently used tools such as, e.g., a weeder harrow or a mechanical implement - a brush weeder - which is not very common in our country (M e l a n d e r et al. 2005). The interest in mechanical methods results from the fact that many herbicides are phytotoxic for herbs ( $\mathrm{Pr}$ i m ot et al. 2006). On the other hand, the results of some field experiments confirm high weed control efficacy of the 
new herbicides tested, without a major negative effect on the herbal plant (M i c h a u d et al. 1993; K u c h a r ski and Mordalski, 2004; K wi at kow ski and Kołodziej, 2005; Kołodziej and Najda, 2007; K w i a t k o w s k i, 2008a, 2008b). In the opinion of Kw i t k ow s ki and Kołodziej (2005) as well as K wi atkowski (2007b), the proper selection of a forecrop for a herbal plant can contribute to an improvement in quality of raw material obtained from such plant in the same way as an effective crop protection method.

The above arguments allowed us to make a hypothesis that the protection of common valerian crops by using a new herbicide mixture, which is not type approved, or through weed management using a mechanical implement (brush weeder), would allow higher yields to be obtained, in terms of their quality and quantity, compared to a traditional manual method of removing emerging weeds, coupled with soil loosening in interrows. It was also assumed that the cultivation of common valerian in a worse stand (winter wheat) could produce satisfactory rhizome and root yields (at a yield level obtained after a root forecrop) thanks to the application of a field pea cover crop.

The aim of this study was to analyse the biometric traits and yielding of common valerian as well as to evaluate the status of weed flora in a crop of this plant as a result of using different weed management methods and two crop stands.

\section{MATERIALS AND METHODS}

The present field study was carried out in the period 2007-2009 in Abramów (Lublin region). The experiment was set up using a split-plot design, with 3 replicates, in $12 \mathrm{~m}^{2}$ plots. Common valerian (var. Lubelski) was grown on grey-brown podzolic soil developed from loess ( $\mathrm{pH}$ in $1 \mathrm{~mol} \mathrm{KCl}=6.4$ ), classified as good wheat complex and characterized by high availability of essential macronutrients ( $\mathrm{P}=$ $\left.169 ; \mathrm{K}=172 ; \mathrm{Mg}=73 \mathrm{mg} \mathrm{kg-}^{1}\right)$. The humus content was $1.52 \%$. Conventional flat cultivation was used in which the density of seedlings (planted in the $1 \mathrm{st}$ decade of May) was 50 x $30 \mathrm{~cm}$ (65 thousand plants per 1 ha) each year. Mineral fertilization was applied in spring at the following amounts, converted into $1 \mathrm{ha}: \mathrm{N}-30 \mathrm{~kg}$ prior to planting and $30 \mathrm{~kg}$ applied as top dressing, $\mathrm{P}-20 \mathrm{~kg}, \mathrm{~K}-40 \mathrm{~kg}$. Mineral $\mathrm{N}$ fertilization was applied in the form of $34 \%$ ammonium nitrate, $\mathrm{P}$ in the form of $46 \%$ granulated triple superphosphate, whereas $\mathrm{K}$ in the form of $50 \%$ potassium salt. factors:
I. Weed control method:

A - manual removal of emerging weeds (hoeing), coupled with soil loosening in interrows at the 3-4 leaf stage (control),

B - recommended herbicides - Reglone Turbo 200 SL (diquat) - 1.51 ha $^{-1}$ - before planting valerian seedlings, and Fusilade Forte 150 EC (fluazifopp-butyl) - $11 \times$ ha- $^{1}-$ at the 3-4 leaf stage,

$\mathrm{C}$ - herbicides not registered for application in common valerian crops - Panida 330 EC (pendimethalin) $1.51 \times$ ha $^{-1}$, and GallantPlus 104EC(haloxyfop-R)$11 \times$ ha $^{-1}-$ at the 3-4 leaf stage,

D - mechanical weed removal in interrows - brush weeder - at the 3-4 leaf stage.

II. Forecrop plant:

1. potato,

2. winter wheat + stubble crop (field pea), ploughed in in autumn.

Conventional tillage was used, adapted to the specificity of the plant in question. The herbicides (treatments B-C) were applied using a field sprayer under a pressure of $0.25 \mathrm{MPa}$. The brush weeder (treatment D) is a mechanical machine, PTO-powered and equipped with brushes with semi-rigid plastic bristles. The brushes are mounted on a vertical axle; they cover a row and "sweep out" weeds in interrows (B o n d and Grund y, 2001). The crop plant is protected against damage by special crop shields. This implement makes it possible to remove weeds at a row spacing of 25-50 $\mathrm{cm}$, growing very near to the crop plants, about 3-4 $\mathrm{cm}$ from each side of the row ( $\mathrm{V}$ a $\mathrm{n}$ der $\mathrm{W}$ e i d e et al. 2005).

At full growth of common valerian (the 6 to 8 leaf stage), during the culmination of development and harmfulness of the weed flora (Kwiatk ow s ki, 2008a), an evaluation of in-crop weed infestation was made using the botanical and gravimetric method, during which the number, species composition and weight of weeds were determined in each plot, within a 0.5 x $1 \mathrm{~m}^{2}$ frame, in two replicates. Roots and rhizomes were harvested in the first decade of October. After harvest, raw material was rinsed and cleaned, then dried in a drying oven at a temperature of $35^{\circ} \mathrm{C}$ and subjected to measurements in order to determine the following: weight, number, diameter and length of roots. The biometric traits were determined based on 30 randomly selected organs sampled from each plot. After drying, the roots and rhizomes were subjected to qualitative analysis which was conducted based on Polish Pharmacopoeia VIII. The determination of essential oil content was made using steam distillation (method 2.8.12., Polish Pharmacopoeia VIII), whereas the valerenic acid content was determined by the liquid chromatography method (methanol) using a spectrophotometer (method 2.2.29., Polish Pharmacopoeia VIII). 
The study results were statistically verified, determining the significance of differences using Tukey's test, with a $5 \%$ risk of error.

\section{RESULTS AND DISCUSSION}

The weed control method and type of forecrop had a significant effect on the average number of common valerian roots (Table 1). The highest number of roots was found under the treatment $\mathrm{C}$ conditions (weed control using the herbicides which are not type approved for application in herbs - pendimethalin + haloxyfop-R). The number of valerian roots per plant in the abovementioned treatment was higher by $24 \%$ compared to the parameter concerned in the control treatment (A), as well as by $21 \%$ (relative to treatment B) and $8 \%$ (treatment D). The application of mechanical weed management in the common valerian crops using the brush weeder (D) resulted in a significant increase in the number of roots per plant compared to treatments A and B by $17 \%$ and $15 \%$, respectively. The cultivation of common valerian in the stand after potato promoted the formation of a larger number of roots, by ca. $5 \%$ compared to that recorded in the treatments with a cereal forecrop and a cover crop.

Table 1

Number of common valerian roots per plant (in pcs.) - mean for 2007-2009

\begin{tabular}{cccccc}
\hline Specification & \multicolumn{5}{c}{ Weed control method } \\
\hline Forecrop & $\mathrm{A}^{*}$ & $\mathrm{~B}^{* *}$ & $\mathrm{C}^{* * * *}$ & $\mathrm{D}^{* * * *}$ & Mean \\
\hline Potato & 136 & 139 & 175 & 161 & 153 \\
\hline Winter wheat + cover crop & 127 & 132 & 170 & 156 & 146 \\
\hline Mean & 131 & 135 & 172 & 158 & - \\
\hline
\end{tabular}

$\mathrm{LSD}_{0.05}$ for:

weed control method $=9.4$

forecrop $=6.6$

A* - manual weed removal (hoe) at the 3-4 leaf stage of valerian (control)

$\mathrm{B} * *$ - herbicides (diquat) - before planting valerian seedlings and (fluazifop-p-butyl) - at the 3-4 leaf stage of valerian

C*** - herbicides (pendimethalin + haloxyfop-R) at the 3-4 leaf stage of valerian

D**** - mechanical weed management (brush weeder) - at the 3-4 leaf stage of valerian

The introduction of the mixture of herbicides (pendimethalin + haloxyfop-R) into the experiment and the use of the brush weeder resulted in obtaining the significantly longest roots of common valerian compared to the only hoed treatment (A) and the plot weeded with the recommended herbicides (treatment B). In this case, root length increased by ca. 6-10\%. The forecrop plants (potato, wheat + cover crop) had practically no influence on valerian root length (Table 2).

Table 2

Common valerian root length (in $\mathrm{cm}$ ) - mean for 2007-2009

\begin{tabular}{cccccc}
\hline \multicolumn{1}{c}{ Specification } & \multicolumn{3}{c}{ Weed control method } \\
\hline Forecrop & A & B & C & D & Mean \\
\hline Potato & 15.9 & 15.5 & 17.4 & 16.7 & 16.4 \\
\hline Winter wheat + cover crop & 15.4 & 15.2 & 17.1 & 16.3 & 16.0 \\
\hline Mean & 15.6 & 15.3 & 17.2 & 16.5 & - \\
\hline $\begin{array}{l}\text { LSD } \\
\text { weed control method }\end{array}$ for: 0.73 \\
\begin{tabular}{l} 
forecrop $=$ rn-ns \\
\hline
\end{tabular}
\end{tabular}

Explanations in Table 1 
Weed removal in the interrows using the mechanical implement - brush weeder - had the most advantageous effect on the thickness of common valerian roots (Table 3 ). Significantly thicker roots of this plant were then obtained in comparison to the control treatment A (by 14\%) and in particular relative to treatment B (by 20\%). Weed management by applying the mix- ture of herbicides not type approved for use in valerian plantations (treatment C) also produced a measurable effect in the form of increased root thickness (by 15\%) relative to treatment $\mathrm{B}$ (weed control using the recommended herbicides). The crop stand did not have a visible effect on the morphological traits of valerian roots.

Table 3

Common valerian root thickness (in mm) - mean for 2007-2009

\begin{tabular}{cccccc}
\hline Specification & \multicolumn{5}{c}{ Weed control method } \\
\hline Forecrop & A & B & C & D & Mean \\
\hline Potato & 3.1 & 2.9 & 3.4 & 3.6 & 3.2 \\
\hline Winter wheat + cover crop & 3.0 & 2.7 & 3.2 & 3.5 & 3.1 \\
\hline Mean & 3.0 & 2.8 & 3.3 & 3.5 & - \\
\hline
\end{tabular}

$\mathrm{LSD}_{0.05}$ for:

weed control method $=0.41$

forecrop $=\mathrm{rn}-\mathrm{ns}$

Explanations in Table 1

There are few studies on the effect of weed control methods in common valerian crops on the morphological traits of this plant. It can only be said that the biometric parameters of valerian roots obtained in the present experiment were within the range characterizing the morphological traits of the variety Lubelski, and they were close to the results obtained by other authors (Gruszczyk, 2007; S zczepanik and $\mathrm{W}$ i śn i ew s ki , 2009). Root thickness is of particularly great importance for the technological value of common valerian raw material. Thick-root raw material is preferred by farmers. Thicker roots are easier to clean and they reduce losses at harvest and during drying, which has a beneficial effect on herbal raw material yields (K w i a t k o w s k i, 2008a).
Irrespective of the type of forecrop, roots dominated in total yield of common valerian raw material (75-79\%) relative to rhizomes (21-25\%) - Table 4, which is in agreement with the observations of $\mathrm{G} \mathrm{r} \mathrm{u} \mathrm{s} \mathrm{z} \mathrm{c} \mathrm{z} \mathrm{y} \mathrm{k}$ (2007). The weed control method used in the valerian plantation did not significantly affect the proportion of roots in yield. However, it should be noted that there was a clear tendency towards an increasing proportion of roots and a significant decline in the proportion of rhizomes in total yield as a result of mechanical weed removal (treatments A and D), coupled with soil loosening in the interrows.

Table 4

Percentage of common valerian roots and rhizomes in total yield (\%), irrespective of the forecrop - mean for 2007-2009

\begin{tabular}{ccc}
\hline \multirow{2}{*}{ Specification } & \multicolumn{2}{c}{ Percentage of roots and rhizomes (\%) } \\
\cline { 2 - 3 } & roots & rhizomes \\
\hline A & 78.2 & 21.8 \\
\hline B & 75.1 & 24.9 \\
\hline C & 76.2 & 23.8 \\
\hline D & 78.8 & 21.2 \\
\hline $\mathrm{LSD}_{0.05}$ & rn-ns & 2.14 \\
\hline
\end{tabular}

Explanations in Table 1 
Table 5

Yield of common valerian roots and rhizomes (in $\left.\mathrm{t} \times \mathrm{ha}^{-1}\right)-$ mean for 2007-2009

\begin{tabular}{|c|c|c|c|c|c|}
\hline Specification & & & ontrol & & \\
\hline Forecrop & A & B & $\mathrm{C}$ & $\mathrm{D}$ & $\begin{array}{c}\text { Średnio } \\
\text { Mean }\end{array}$ \\
\hline Potato & 3.36 & 3.45 & 4.02 & 3.90 & 3.68 \\
\hline Winter wheat + cover crop & 3.24 & 3.22 & 3.88 & 3.79 & 3.53 \\
\hline Mean & 3.30 & 3.33 & 3.95 & 3.84 & - \\
\hline \multicolumn{6}{|l|}{$\begin{array}{l}\mathrm{LSD}_{0.05} \text { for: } \\
\text { seed control method }=0.462 \\
\text { forecrop }=\mathrm{rn} \text {-ns }\end{array}$} \\
\hline
\end{tabular}

Explanations in Table 1

Table 6

Essential oil content in common valerian roots and rhizomes (in \% ADW) - mean for 2007-2009

\begin{tabular}{cccccc}
\hline Specification & \multicolumn{5}{c}{ Weed control method } \\
\hline Forecrop & A & B & C & D & Mean \\
\hline Potato & 1.01 & 0.78 & 0.82 & 1.14 & 0.93 \\
\hline Winter wheat + cover crop & 0.80 & 0.61 & 0.73 & 0.88 & 0.81 \\
\hline Mean & 0.90 & 0.69 & 0.77 & 1.01 & - \\
\hline
\end{tabular}

$\operatorname{LSD}_{0.05}$ for:

weed control method $=0.094$

forecrop $=0.082$

Explanations in Table 1

Table 7

Valerenic acid content in common valerian roots and rhizomes (in \% ADW) - mean for 2007-2009

\begin{tabular}{ccccccc}
\hline Specification & \multicolumn{5}{c}{ Weed control method } \\
\hline Forecrop & A & B & C & D & Mean \\
\hline Potato & 0.21 & 0.16 & 0.18 & 0.23 & 0.19 \\
\hline Winter wheat + cover crop & 0.17 & 0.13 & 0.14 & 0.17 & 0.15 \\
\hline Mean & 0.19 & 0.14 & 0.16 & 0.20 & - \\
\hline
\end{tabular}

$\mathrm{LSD}_{0.05}$ for:

weed control method $=0.028$

forecrop $=0.026$

Explanations in Table 1 
Table 8

Air-dry weight of weeds in a common valerian crop $\left(\right.$ in $\left.\mathrm{g} \times \mathrm{m}^{-2}\right)-$ mean for 2007-2009

\begin{tabular}{cccccc}
\hline \multicolumn{1}{c}{ Specification } & \multicolumn{5}{c}{ Weed control method } \\
\hline Forecrop & A & B & C & D & Mean \\
\hline Potato & 39.7 & 32.3 & 17.4 & 18.9 & 27.1 \\
\hline Mean & 50.2 & 41.6 & 20.6 & 21.2 & 33.4 \\
\hline Winter wheat + cover crop & 44.9 & 36.9 & 19.0 & 20.0 & - \\
\hline $\begin{array}{l}\text { LSD } \\
\text { weed control method }=6.19 \\
\text { forecrop }=5.01\end{array}$ & & & & & \\
\hline
\end{tabular}

Explanations in Table 1

Table 9

Negative effect of herbicides and mechanical measures on common valerian plants at the 3-4 leaf stage (2 weeks after treatment); percentage of damaged valerian plants - mean for 2007-2009

\begin{tabular}{cccccc}
\hline Specification & \multicolumn{5}{c}{ Weed control method } \\
\hline Forecrop & A & B & C & D & Mean \\
\hline Potato & 0.8 & 0.2 & 7.0 & 5.1 & 3.3 \\
\hline Winter wheat + cover crop & 0.4 & 0.4 & 6.2 & 5.3 & 3.1 \\
\hline Mean & 0.6 & 0.3 & 6.6 & 5.2 & - \\
\hline
\end{tabular}

$\mathrm{LSD}_{0.05}$ for:

weed control method $=3.26$

forecrop $=$ rn-ns

Explanations in Table 1

The average total yield of common valerian roots and rhizomes, expressed in $\mathrm{tha}^{-1}$, showed a significant correlation with the weed control methods used in the experiment (Table 5). The traditional weed management methods involving hand hoeing in the interrows (A) or the application of the "conventional" herbicides (B) had a smaller effect on common valerian productivity in comparison with the innovative weed control methods (treatments $\mathrm{C}$ and $\mathrm{D}$ ). The herbicide mixture (pendimethalin + haloxyfop-R) resulted in increased valerian yields by ca. $16 \%$ compared to treatments $\mathrm{A}$ and $\mathrm{B}$, whereas weed removal using the brush weeder increased raw material yields of this plant by ca. $14 \%$. In spite of the absence of significant differences, the stand after potato proved to be more advantageous for valerian productivity in comparison with the cereal forecrop supported by cover cropping. The difference in valerian yield was $0.15 \mathrm{t} \mathrm{ha}^{-1}$ in favour of the root forecrop.
Earlier studies of K w i t k ow s ki (2008a; $2008 b$ ) on weed control methods in common valerian crops show, similarly to the results of the experiment in question, that it is highly advisable to test herbicides not registered for application in crops of this plant. They showed a positive impact of some herbicide mixtures such as, e.g., metamitron + fluazifop-p-butyl, 2.4-D + dicamba + fluazifop-p-butyl, metamitron + propaquizafop as well as pendimethalin + haloxyfop-R, on valerian productivity, without any clear phytotoxic effect on this herbal plant. In turn, field experiments with the use of a brush weeder in interrows of other herbal plants (sweet basil) prove the great usefulness of this mechanical implement in weed management and in the stimulation of increased yields of herbal raw material (B o n d and G rund y, 2001; K w i a t k o w s k i, 2009). The effectiveness of the brush weeder, and thereby the minimization of damage to the crop plant, is closely correlated to weather conditions and soil 


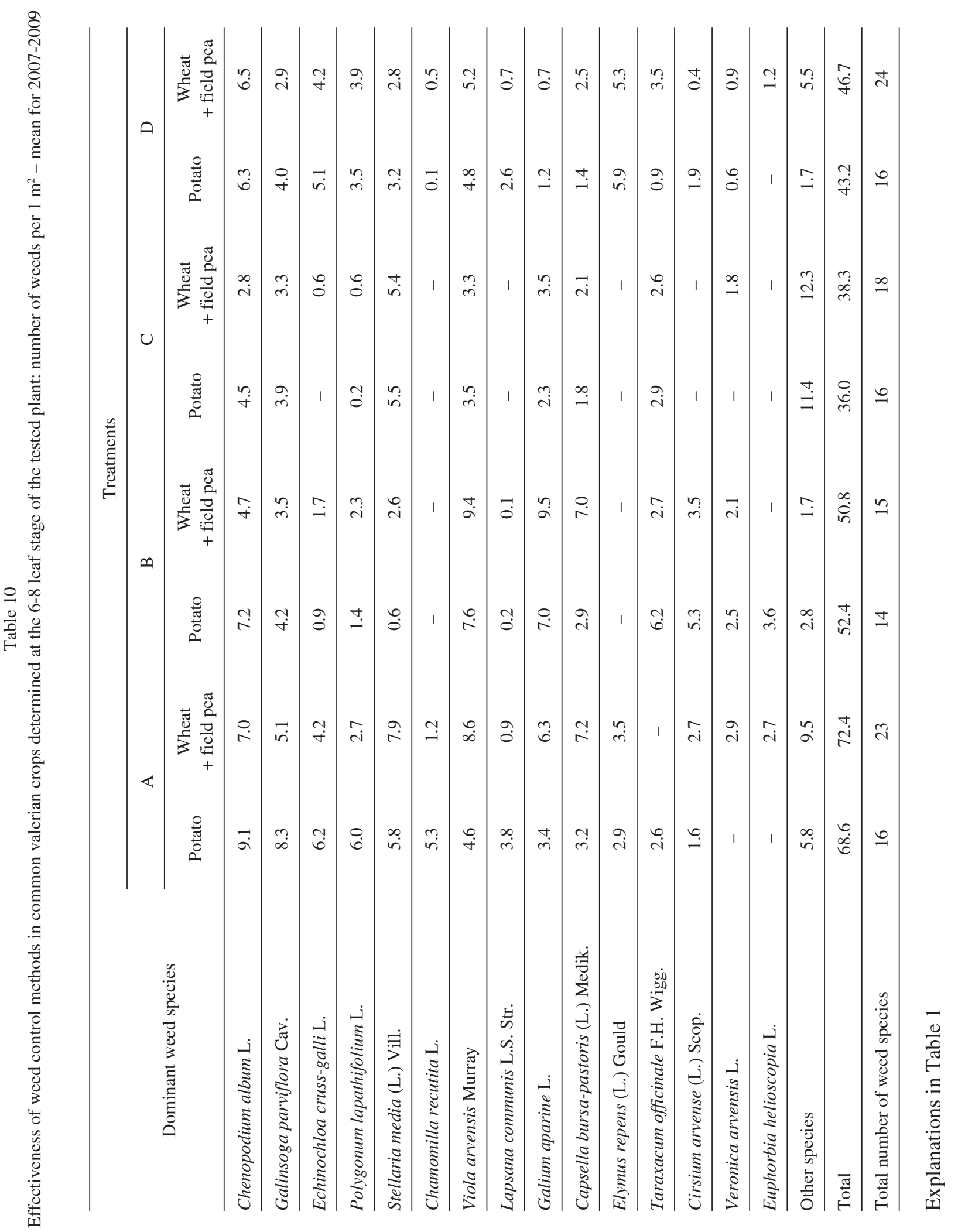


type. Under conditions of high soil moisture content, a larger number of uprooted and broken plants are noted due to problems with guiding this implement evenly in interrows in such conditions ( $\mathrm{V}$ a n de $\mathrm{r}$ Weide et al. 2005; K w i at k ow ski, 2009).

The present experiment found a small impact of the crop stand on common valerian productivity and its morphological traits. Nevertheless, potato proved to be a better forecrop for common valerian. Studies on the effect of a forecrop plant on common thyme yielding, carried out by Kwiatkowski and Kołodziej (2005) as well as by K wi a t k ow ski (2007b), confirm the positive impact of a root forecrop on weed infestation reduction, thereby on increased productivity of a herbal plant. Root forecrops are also recommended for valerian by R u m i ń s k a (1991).

From the point of view of the pharmaceutical industry, the chemical composition of common valerian raw material is the most important. The present study results demonstrate that the significantly highest content of both essential oil (Table 6) and valerenic acids (Table 7) was obtained from roots and rhizomes harvested from the plots in which the mechanical weed removal methods had been used (treatments A and D), which is confirmed by earlier studies of $\mathrm{Kwi}$ at k ow ski (2008b). Chemical weed control, regardless of herbicide type, resulted in a decrease in essential oil content by $0.13-0.32 \%$ of dry weight (DW), whereas in the case of valerenic acids by $0.03-0.06 \%$ of air-dry weight (ADW) compared to the mechanical methods (Tabs 6-7). The forecrop also had a significant effect on the chemical composition of common valerian. The cultivation of this herbal plant in the stand after potato resulted in an increased content of essential oil and valerenic acids by $0.12 \%$ and $0.04 \%$ ADW, respectively, relative to the results from the treatments in which the cereal forecrop had been used. A study by Gruszczyk (2007) also shows that ecological or integrated methods of common valerian cultivation produce a more beneficial impact on the chemical composition of raw material than conventional methods oriented towards chemical crop protection. However, it should be noted that in the present study the content of essential oil and valerenic acids, irrespective of the weed control method, was at a level which did not differ from the recommended standards and was close to the results reported by other authors (B o s et al. 1998; Moniuszko and Wiśniewski, 2001; Kołodziej and Najda, 2007; Szczepanik and Wiśniewski, 2009 ).

The weed control method had a significant effect on air-dry weight of weeds in the common valerian crop (Table 8) The highest weed weight was found in the control plot A, only hoed, and then in plot B treated with the herbicides recommended by the Plant
Protection Institute in Poznań. The new weed management methods (chemical and mechanical control - treatments $\mathrm{C}$ and D) allowed air-dry weight of weeds to be reduced to a level of $19-20 \mathrm{~g} \times \mathrm{m}^{-2}$, i.e. a value more than twice smaller than that recorded in the control treatment and smaller by $47 \%$ compared to treatment B. The winter wheat forecrop, together with the cover crop, significantly promoted higher weed infestation of the common valerian crop (by 19\%), relative to the stand after the root plant, irrespective of the weed control method.

The weed management methods under investigation resulted in varying degrees of damage to the herbal plant in question (Table 9). The significantly lowest, and at the same time marginal, percentage of damage to valerian plants $(0.3-0.6 \%)$ was observed for treatments A and B (traditional weed control) compared to the innovative protection methods (C-D) which caused damage in plants at a level of $5-6 \%$. The valerian plants regenerated after $2-3$ weeks, while the damage had no effect whatsoever on yield quality and levels. Similar tendencies were observed by Kwiatkowski (2009) in the cultivation of sweet basil.

The effectiveness of the weed control methods and, to a lesser degree, of the forecrop applied was also reflected in the numbers of dominant weed species in the valerian crop (Table 10). The number of weeds showed a linear correlation with their air-dry weight (Table 8) and had the highest values for treatment $\mathrm{A}$ in which the following weed species were predominant: Chenopodium album, Galinsoga parviflora, Echinochloa cruss-galli (in the stand after potato) as well as Stellaria media, Viola arvensis, Capsella bursapastoris and Galium aparine (wheat + field pea). The application of the herbicides recommended by the Plant Protection Institute (treatment B) reduced the total number of weeds by $24-30 \%$, but it promoted the propagation of some annual (Viola arvensis, Galium aparine) and perennial (Taraxacum officinale, Cirsium arvense) dicotyledonous species. The introduction of the herbicide mixture composed of pendimethalin + haloksyfop-R (treatment $\mathrm{C}$ ) resulted in a reduction in the numbers of all dominant weed species in comparison to the control treatment (nearly twice, on average). The use of the brush weeder (treatment D) also limited effectively the quantitative development of the dominant weed species, resulting only in a compensation of the following monocotyledonous weeds: Echinochloa crus-galli and Elymus repens, probably due to the incomplete destruction of their root systems and, as a consequence, their quick regrowth. Regardless of the species composition of weeds, the mechanical protection methods caused the formation of species-richer communities (16-24 species), whereas the chemical 
methods reduced the biodiversity (14-18 species). The above described weed infestation levels in the common valerian crops, as dependent on the protection method and forecrop, are similar to the results of studies, reported in other papers, relating to common valerian (K w i a t k ow s k i, 2008a; 2008b) and other herbal plants (Michaud et al. 1993; Kucharski and Mordalski, 2004; Kwiatkowski and Kołodziej, 2005; Melander et al. 2005; K w i at k ow s ki , 2007b, 2009).

\section{CONCLUSIONS}

1. Weed control with foliar-applied herbicides (pendimethalin + haloxyfop-R) and by using a mechanical implement - brush weeder - contributed to obtaining the highest yields of common valerian roots and rhizomes with the best morphological parameters. It also caused a low degree of damage to this herbal plant. The above methods resulted in an effective reduction of the quantitative levels of in-crop weed infestation in comparison with the traditional (mechanical and chemical) weed control methods.

2. The selection of a forecrop was of secondary importance for the yield structure and weed infestation of common valerian.

3. The mechanical weed management method and growing common valerian in the stand after potato produced the best chemical composition of common valerian raw material (the content of essential oil and valerenic acids). The chemical crop protection methods did not have a destructive effect on the content of the abovementioned constituents of valerian roots and rhizomes, with their values at the level of accepted qualitative standards.

4. Weed control in common valerian crops by the application of herbicides (pendimethalin + haloxyfop-R) or the use of the brush weeder had a beneficial influence on productivity of this herbal plant. The above methods can be recommended for use in agricultural practice under similar soil and climatic conditions.

\section{REFERENCES}

Bos R., Woerdenbag H. J., Van Putten F. M. S., Hendriks H., Scheffer J. J. C. Seasonal variation of the essential oil, valerenic acid and derivatives and valepotriates among in Valeriana officinalis roots and rhizomes, and the selection of plants suitable for phytomedicines. Planta Med. 64: 143-147.

B ond W., Gr und y A., 2001. Non-chemical weed management in organic farming systems. Weed Res. 41: 385-405.

Farmakopea Polska VIII. 2008. Polskie Towarzystwo Farmaceutyczne, Warszawa, Tom V: 507-511 (in Polish).
Gruszczyk M., 2007. The effect of ecological cultivation on yield and qualitative characteristics of common valerian (Valeriana officinalis L.) raw material. Herba Polonica, 53 (3): 197-201.

Kwiatkowski C., 2007a. Evaluation of chemical and mechanical ways for weed control in garden thyme (Thymus vulgaris L.) grown for herbs. Herba Polonica, 53 (3): 202-206.

Kw i at kowsk i C., 2007b. Zachwaszczenie i plonowanie tymianku właściwego (Thymus vulgaris L.) w zależności od sposobu pielęgnacji i przedplonu. / Weed infestation and yielding of garden thyme (Thymus vulgaris L.) in relation to protection method and forecrop. Progress in Plant Protection / Postępy w Ochronie Roślin 47 (3): 187-190 (in Polish).

Kw i a t k ow sk i C., 2008a. Influence of selected herbicides on weed infestation and yielding of common valerian ( $\mathrm{Va}$ leriana officinalis L.). Herba Polonica, 54 (2): 13-21.

Kwiatkowski C., 2008b. Ocena wybranych herbicydów $\mathrm{w}$ uprawie kozłka lekarskiego (Valeriana officinalis L.). / Evaluation of selected herbicides in cultivation of common valerian (Valeriana officinalis L.). Postępy w Ochronie Roślin, 48 (1): 287-290 (in Polish).

Kwiatkowski C., 2009. Ocena przydatności niektórych narzędzi oraz herbicydów w regulacji zachwaszczenia bazylii pospolitej (Ocimum basilicum L.) uprawianej na surowiec zielarski. / Evaluation of some mechanical methods and herbicides in weed management of sweet basil (Ocimum basilicum L.) grown for herbs. Ann. UMCS, Sect. E 64, (3): 58-68 (in Polish).

Kwiatkowski C., Kołodziej B., 2005. Wpływ przedplonu i sposobu pielęgnacji na zachwaszczenie łanu i jakość surowca tymianku właściwego (Thymus vulgaris L.). / The effect of forecrop and protection method on canopy weed infestation and raw material quality of thyme (Thymus vulgaris L.). Ann. UMCS, Sect. E, 60: 175-184 (in Polish).

Kołodziej B., Najda A., 2007. Plantation establishment methods in cultivation of chosen medicinal plants. Herba Polonica, 53 (3): 268-272.

Kucharski M., Mordalski R., 2004. Zwalczanie chwastów jedno- i dwuliściennych w uprawie żmijowca zwyczajnego (Echium vulgare L.) na surowiec zielarski. / Broadleaf and grass weed control in cultivation of viper's bugloss (Echium vulgare L.) for herbal raw material. Postępy w Ochronie Roślin, 44 (2): 990-992 (in Polish).

Melander B., Ras musen I. A., B arberi P., 2005. Integrating physical and cultural methods of weed control examples from European Research. Weed Sci. 53: 369381.

Michaud M., Gosselin A., Tremblay N., Benoit D., B el anger A., D e sroches B., 1993. Effect of a herbicide and two grown in Quebec (Canada). Acta Hort. 331: 311-318.

Moniuszko M., Wiśniewski J., 2001. Wpływ metody uprawy i obsady roślin na plonowanie oraz skład che- 
miczny kozłka lekarskiego (Valeriana officinalis L.). I The influence of cultivation method and plant density on yielding and chemical composition of common valerian (Valeriana officinalis L.). Ann. UMCS, Sect. E, 9 (Supl.): 107-112 (in Polish).

Primot S., Valantin-Morison M., Makowski D., 2005. Predicting the risk of weed infestation in winter oil seed rape crops. Weed Res. 46: 22-23.

Rumińska A., 1991. Poradnik plantatora ziół. Państwowe Wydawnictwo Rolne i Leśne Poznań: 200-208 (in Polish).

Szczepanik M., Wiśniewski J., 2009. Porównanie plonowania oraz cech jakościowych surowca trzech odmian kozłka lekarskiego (Valeriana officinalis L.) uprawianego z rozsady. / Comparison of yield and qualitative characteristics of raw material of three cultivars of common valerian (Valeriana officinalis L.) cultivated from seedlings. Zeszyty Problemowe Postępów Nauk Rolniczych, 542 (1): 511-516 (in Polish).

Van der Weide R. V., Bleeker P., Molema G. J., Lotz L. A. P., Fogelberg F., Mel ander B., 2005. Innovation in mechanical weed control in row crops. 13th EWRS Symposium, Bari 19-23 June 2005: 174.

\section{Ocena jakości plonu \\ oraz zachwaszczenia kozłka lekarskiego (Valeriana officinalis $\mathbf{L}$.) w zależności od sposobu odchwaszczania i przedplonu}

\section{Streszczenie}

Eksperyment polowy z uprawą kozłka lekarskiego przeprowadzono w latach 2007-2009 w Abramowie (woj. lubelskie), na glebie lessowej. Oceniano parametry jakościowe surowca tej rośliny oraz zachwaszczenie łanu $\mathrm{w}$ zależności od sposobu pielęgnacji i przedplonu. Obiektem kontrolnym były poletka odchwaszczane ręczną gracą. Na pozostałych obiektach zwalczano chwasty przy pomocy różnych herbicydów oraz aktywnego narzędzia (pielnik szczotkowy). Przedplonem dla kozłka lekarskiego był ziemniak oraz pszenica ozima + międzyplon z grochu polnego. Przyjęto hipotezę, że zastosowanie pielnika szczotkowego oraz herbicydów nie zarejestrowanych do aplikacji w zasiewach kozłka wpłynie pozytywnie na produkcyjność i zachwaszczenie tej rośliny. Założono również, że wprowadzenie międzyplonu pozwoli na zniwelowanie różnic $\mathrm{w}$ wartości przedplonowej analizowanych stanowisk uprawy.

Najkorzystniejsze parametry ilościowe i jakościowe surowca kozłka lekarskiego, jak również największą redukcję zachwaszczenia łanu notowano po aplikacji herbicydów nie mających atestu. Korzystne oddziaływanie na produkcyjność analizowanej rośliny posiadało także zastosowanie pielnika szczotkowego w międzyrzędziach, którego wadą okazało się zachwaszczenie wtórne pod koniec wegetacji kozłka. Tradycyjne metody pielęgnacji zasiewów kozłka były mniej skuteczne w ograniczeniu zachwaszczenia i wpływały na obniżenie produkcyjności i jakości surowca. Ziemniak okazał się korzystniejszym przedplonem dla kozłka lekarskiego niż pszenica ozima + groch polny, jednak pozytywnego oddziaływania przedplonu nie potwierdzono statystycznie. W łanie kozłka lekarskiego dominowały chwasty krótkotrwałe: Chenopodium album, Galinsoga parviflora, Stellaria media. Tradycyjne metody odchwaszczania skutkowały dominacją niektórych chwastów dwuliściennych, jak Viola arvensis, Galium aparine, Capsella bursa-pastoris. 